\title{
Overview of 13 years of research on radionuclide behavior in Brazilian soils
}

\author{
M.A. Wasserman \\ Instituto de Radioproteção e Dosimetria/CNEN. Av. Salvador Allende s/n ${ }^{\circ}$, \\ 22780-160 Recreio, Rio de Janeiro, RJ, Brasil
}

\begin{abstract}
Since the Goiânia Accident in 1987, the Environmental Impact Assessment Service of the Institute of Radioprotection and Dosimetry started developing studies aiming to improve response for nuclear and radiological accidents. In 1993 radioecological studies for determining transfer factors adequate to main types of agricultural soils and crops cultivated in Brazil. While the studies proceeded, it was felt that mechanisms involved in soil-plant processes should be better understood. Sequential extraction was seen as an important tool to understand radionuclide behavior in the soil-plant system. After 15 years studying different types of tropical soils and several radionuclides, such as ${ }^{137} \mathrm{Cs},{ }^{90} \mathrm{Sr}$ and ${ }^{60} \mathrm{Co}$, it could be seen the relevance of site specific data to be used for environmental impact assessments and to the decision making process after an accidental contamination, and that these assessments need to be based on the knowledge of environmental processes governing the long term behavior of radionuclides at a specific type of environment.
\end{abstract}

\section{INTRODUCTION}

Environmental studies after the accident of Chernobyl contributed to improve the knowledge on the behavior of artificial radionuclide in temperate areas, supplying consistent information to the management of contaminated agricultural areas. In Brazil, the Goiânia accident with ${ }^{137}$ Cs in 1987 , pulled to reinforce the knowledge related to the management of urban contaminated areas and remedial actions, whereas for tropical agricultural areas very few information was available at this time. Highly weathered soils as Ferralsol and Acrisol are predominant in the Brazilian territory, occupying extensive cultivated areas. They represent important natural reservoirs, with a great potential role for solving problems associated with to the food production and environmental protection.

Since 1993 at the Environmental Impact Assessment Service of the Institute of Radioprotection and Dosimetry, experimental studies were carried out on Brazilian soils, artificially contaminated with ${ }^{137} \mathrm{Cs}$, ${ }^{60} \mathrm{Co}$ and ${ }^{90} \mathrm{Sr}$ and an urban soil contaminated with ${ }^{137} \mathrm{Cs}$ from the Goiânia accident [1-9]. These studies integrated results of soil to plant transfer factor for several crops groups growing in lysimeters or pots, with results of experiments conducted in laboratory, to understand the main components or properties of soils involved on the mechanisms of sorption for a given radionuclide. This extended abstract presents an overview of more than 13 years of studies carried out on the fate of radionuclide in these Brazilian soils, in order to acquire regional knowledge on the radioecology of tropical agroecosystems and aiming to improve radiological assessments that allows to optimization of countermeasures.

\section{MATERIALS AND METHODS}

Since 1993, different crops have been cultivated in three types of Ferralsol (goethite rich-Ferralsol-Fe; gibbsite rich Ferralsol-Al and an acid Ferralsol), one Acrisol (kaolinite rich), two types of Nitisol (one collected in the South of Brazilian territory under subtropical climate rich in goethite with traces of vermiculite and the other collected in the Southeast part of Brazil under tropical conditions, rich in 
kaolinite), one Histosol (organic matter rich) and one urban soil (gibbsite rich) contaminated in 1987 with ${ }^{137} \mathrm{Cs}$ in the accident of Goiânia (refereed to as Goiânia soil).

The artificial contamination with ${ }^{60} \mathrm{Co}$ and ${ }^{137} \mathrm{Cs}$ was done by spraying a contaminated solution in every $2 \mathrm{~cm}$ layer of soil, up to $40 \mathrm{~cm}$ and, for ${ }^{90} \mathrm{Sr}$, they were spiked by spraying it directly on the soil surface. The values of soil activity and year of contamination for ${ }^{137} \mathrm{Cs},{ }^{60} \mathrm{Co}$ and ${ }^{90} \mathrm{Sr}$ are shown in Table 1. The Soils Office of the Brazilian Agricultural Research Enterprise (EMBRAPASolos) performed the soil analyses, according to their standards manual [10]. The soil to plant transfer factors (TF) were determined as the ratio of the activity in the edible parts of the plant (given in $\mathrm{Bq} \mathrm{kg}{ }^{-1}$ dry weight) and the activity in the first $20 \mathrm{~cm}$ of the soil (given in $\mathrm{Bq} \cdot \mathrm{kg}^{-1} \mathrm{dry}$ weight), following the International Union of Radioecologists recommendations for the contamination and crop treatments [11].

For the sequential chemical extraction, $3 \mathrm{~g}$ of soil samples were used in duplicates, following a five step protocol operationally defined as:

(i) acidic phase $\left[\mathrm{CH}_{3} \mathrm{COOH}+\mathrm{CH}_{3} \mathrm{COONa} 1: 1\right.$; shake at room temperature (RT)]: readily bioavailable elements;

(ii) easily reducible phase $\left[\mathrm{NH}_{2} \mathrm{OH} . \mathrm{HCl}(0.1 \mathrm{M})\right.$; shake at $\left.\mathrm{RT}\right]$ : bound to $\mathrm{Mn}$ oxides;

(iii) oxidizable phase $\left[\mathrm{H}_{2} \mathrm{O}_{2}(30 \%) \mathrm{p} \mathrm{HNO}_{3} ; \mathrm{pH} 2\right.$; shake at RT]: bound to labile organic matter;

(iv) alkaline phase $[\mathrm{NaOH}(0.1 \mathrm{M})$; shake at $\mathrm{RT}]$ : bound to $\mathrm{Fe}$ compounds; and resistant organic compounds;

(v) Resistant phase [aqua regia heat to $50{ }^{\circ} \mathrm{C} / 30 \mathrm{~min}$ ]: material that is not potentially available for transfer processes [7].

The ${ }^{137} \mathrm{Cs}$ and ${ }^{60} \mathrm{Co}$ activity in soil, plants and soil extracts were determined by Gamma Spectrometry using a Ge detector Ortec, while the ${ }^{90} \mathrm{Sr}$ activity was determined by measuring beta activity of Y-90 in a Berthold Low Background Proportional Counter.

Statistical tests were performed using Microsoft EXCEL and the correlation coefficients were obtained using Pearson's correlation test $(\mathrm{P}<0.05)$.

Table 1. ${ }^{137} \mathrm{Cs},{ }^{60} \mathrm{Co}$ and ${ }^{90} \mathrm{Sr}$ mean activity in soil $\left(\mathrm{Bq} \cdot \mathrm{kg}^{-1}\right.$ dry weight $)$ and year of contamination.

\begin{tabular}{ccccccccc}
\hline & $\begin{array}{c}\text { Goiânia } \\
\text { soil }\end{array}$ & $\begin{array}{c}\text { Ferralsol- } \\
\mathrm{Al}\end{array}$ & $\begin{array}{c}\text { Ferralsol- } \\
\mathrm{Fe}\end{array}$ & Acrisol & $\begin{array}{c}\text { Nitisol } \\
\text { subtropical }\end{array}$ & $\begin{array}{c}\text { Ferralsol } \\
\text { acid }\end{array}$ & $\begin{array}{c}\text { Nitisol } \\
\text { tropical }\end{array}$ & Histisol \\
\hline${ }^{137} \mathrm{Cs}$ & $1.8 \mathrm{E}+3$ & $7.0 \mathrm{E}+3$ & $7.1 \mathrm{E}+3$ & $3.3 \mathrm{E}+3$ & $6.8 \mathrm{E}+3$ & $4.8 \mathrm{E}+3$ & $6.3 \mathrm{E}+3$ & $5.9 \mathrm{E}+3$ \\
& $(1987)$ & $(1993)$ & $(2000)$ & $(2000)$ & $(2003)$ & $(2003)$ & $(2003)$ & $(2003)$ \\
${ }^{60} \mathrm{Co}$ & $\mathrm{NC}$ & $\mathrm{NC}$ & $2.6 \mathrm{E}+3$ & $1.3 \mathrm{E}+3$ & $2.6 \mathrm{E}+3$ & $2.3 \mathrm{E}+3$ & $5.7 \mathrm{E}+3$ & $4.5 \mathrm{E}+3$ \\
& & & $(2000)$ & $(2000)$ & $(1996)$ & $(2003)$ & $(2003)$ & $(2003)$ \\
${ }^{90} \mathrm{Sr}$ & $\mathrm{NC}$ & $3,6 \mathrm{E}+2$ & $1,4 \mathrm{E}+2$ & $1,6 \mathrm{E}+2$ & $5,0 \mathrm{E}+2$ & $\mathrm{NC}$ & $\mathrm{NC}$ & $\mathrm{NC}$ \\
& & $(2000)$ & $(2000)$ & $(2000)$ & $(2000)$ & & & \\
\hline
\end{tabular}

$\mathrm{NC}=$ no contamination

\section{RESULTS}

The Ferralsol together with Acrisol, represent more than sixty percent of agricultural Brazilian soils. Their main restrictions for some crops are generally the low nutrient contents and acidity, as showed in Table 2.

One of the most important characteristics of highly weathered soils is the predominance of 1:1 clay minerals type and $\mathrm{Fe}, \mathrm{Al}$ and occasionally, $\mathrm{Mn}$ oxides in the clay fraction, while the 2:1 clay mineral is generally absent. Among the studied soils, the Nitisol, was the only soil with traces of vermiculite (Table 2). This 2:1 phyllosilicate is recognized to be responsible for specific adsorption of ${ }^{137} \mathrm{Cs}$ and for its strong fixation, reducing the soil to plants transfer with time [12]. As so, it is important to note that the Goiânia soil did not show reduction of ${ }^{137} \mathrm{Cs}$ TF for radish with time, even 13 years after soil 
Table 2. Pedological analyses.

\begin{tabular}{|c|c|c|c|c|c|c|c|c|}
\hline & Goiânia & $\begin{array}{c}\text { Ferralsol } \\
A l\end{array}$ & $\begin{array}{c}\text { Ferralsol } \\
\mathrm{Fe}\end{array}$ & $\begin{array}{l}\text { Ferralsol } \\
\text { acid }\end{array}$ & Acrisol & $\begin{array}{l}\text { Nitisol } \\
\text { sub } \\
\text { tropical }\end{array}$ & $\begin{array}{l}\text { Nitisol } \\
\text { tropical }\end{array}$ & Histisol \\
\hline Exchangeable & $0.25-$ & 0.12 & 0.06 & 0.01 & 0.08 & 0.18 & 0.02 & 0.20 \\
\hline $\mathrm{K}\left(\mathrm{cmol} \mathrm{kg}^{-1}\right)$ & $0.11 *$ & & & & & & & \\
\hline Exchangeable & 4.0 & 3.9 & 0.8 & 0.01 & 1.0 & 4.0 & 1.2 & 0.8 \\
\hline $\begin{array}{c}\mathrm{Ca}\left(\mathrm{cmol} \mathrm{kg}^{-1}\right) \\
\mathrm{CEC} \\
\left(\mathrm{cmol} \mathrm{kg}^{-1}\right)\end{array}$ & 4.8 & 4.8 & 5.2 & 5.4 & 6.3 & 6.1 & 10.9 & 41.7 \\
\hline $\mathrm{pH}$ in $\mathrm{KCl}$ & $8.3-7.7 *$ & $4.3-7.4 *$ & 4.5 & 3.9 & 5.4 & 4.2 & 3.8 & 3.5 \\
\hline $\mathrm{OM}(\%)$ & 1.9 & 2.1 & 1.6 & 3.8 & 0.5 & 2.1 & 4.7 & 22.9 \\
\hline $\mathrm{Fe}_{2} \mathrm{O}_{3}(\%)$ & 5 & 3 & 23 & 5 & 2 & 13 & 16 & 4 \\
\hline Clay $\left(\mathrm{g} \mathrm{kg}^{-1}\right)$ & 160 & 180 & 770 & 444 & 90 & 490 & 621 & 489 \\
\hline $\begin{array}{l}\text { Sand }\left(\mathrm{g} \mathrm{kg}^{-1}\right) \\
\text { Main clay } \\
\text { mineral type }\end{array}$ & $\begin{array}{l}680 \\
\text { gibbsite, } \\
\text { kaolinite }\end{array}$ & $\begin{array}{c}710 \\
\text { gibbsite, } \\
\text { kaolinite }\end{array}$ & $\begin{array}{c}190 \\
\text { hematite, } \\
\text { goethite }\end{array}$ & $\begin{array}{c}127 \\
\text { kaolinite }\end{array}$ & $\begin{array}{c}820 \\
\text { kaolinite }\end{array}$ & $\begin{array}{c}100 \\
\text { hematite, } \\
\text { goethite, } \\
\text { vermiculite }\end{array}$ & $\begin{array}{c}123 \\
\text { kaolinite }\end{array}$ & $\begin{array}{c}47 \\
\text { kaolinite }\end{array}$ \\
\hline
\end{tabular}

contamination (Figure 1) and the decreases in the ${ }^{137} \mathrm{Cs} \mathrm{TF}$, observed at Ferralsol were associated with change in soil $\mathrm{pH}$ due to liming, from a $\mathrm{pH}=4.8$ at 4YAC up to 7.4 at 8 YAC [4].

More than 10 years after the contamination, the tropical soils still present ${ }^{137} \mathrm{Cs} \mathrm{TF}$ one order of magnitude higher than TF recommended by IUR to be used for dose assessment in the absence of regional values [11].

On the other hand, the lower ${ }^{137} \mathrm{Cs} \mathrm{TF}$ that occurred in Nitisol (in this case, subtropical), independent of time elapsed from the contamination or crop type (Figures 1 and 2), indicated a different mechanism in the control of the radionuclide behavior compared with the other tropical soils. This is probably due to the presence of vermiculite, although as a trace compound. Higher values of ${ }^{137} \mathrm{Cs}$ TF occurred mainly associated with acid and unfertile soils, contaminated lately: Acrisol (Figure 2). Despite of this natural high vulnerability to ${ }^{137} \mathrm{Cs}$ contamination, Ferralsol and Nitisol respond quite well to agricultural practices like liming [5] and organic amendments [8], reducing its soil to plant transfer factors.

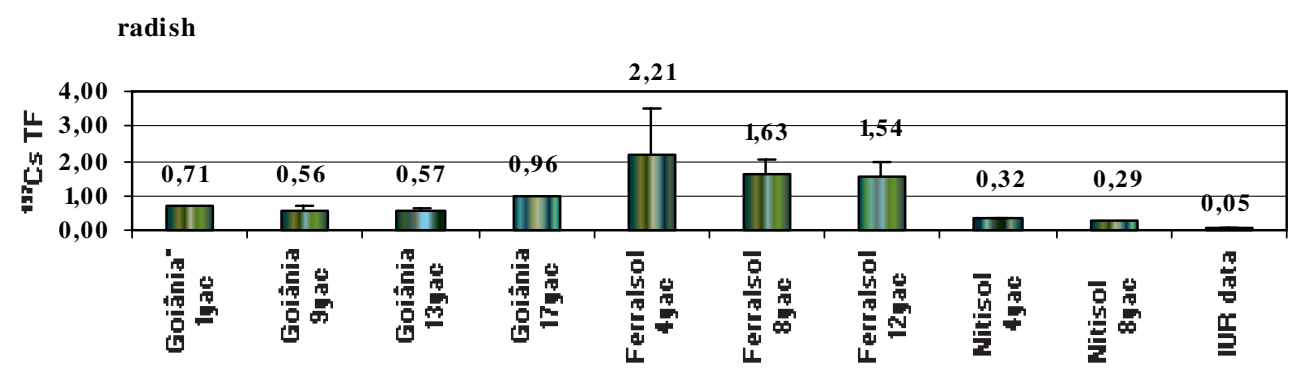

Figure 1. ${ }^{137} \mathrm{Cs}$ Soil to plant transfer Factor for radish (YAC = years after soil contamination).

The geochemical partitioning of ${ }^{137} \mathrm{Cs}$, revealed similar partition between Ferralsol-Al and FerralsolGo, consistent with similar soil properties at these data and similar TF values [7]. According to Wasserman et al. [9], around $10 \%$ of ${ }^{137} \mathrm{Cs}$ in soil was still easily available for root uptake 9 years after contamination in the Ferralsol-Al, while very low percentage of this radionuclide (3\%) was available for 


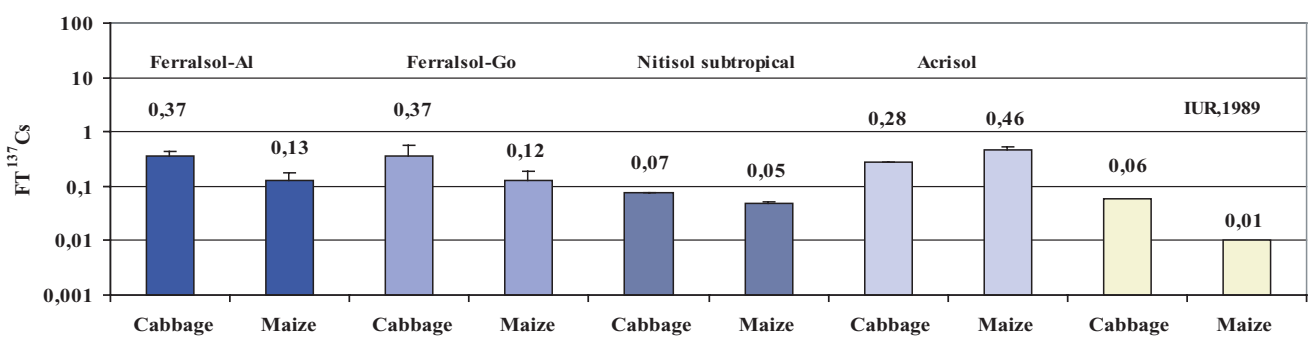

Figure 2. ${ }^{137}$ Cs Soil to Plant Transfer Factor for maize and cabbage.

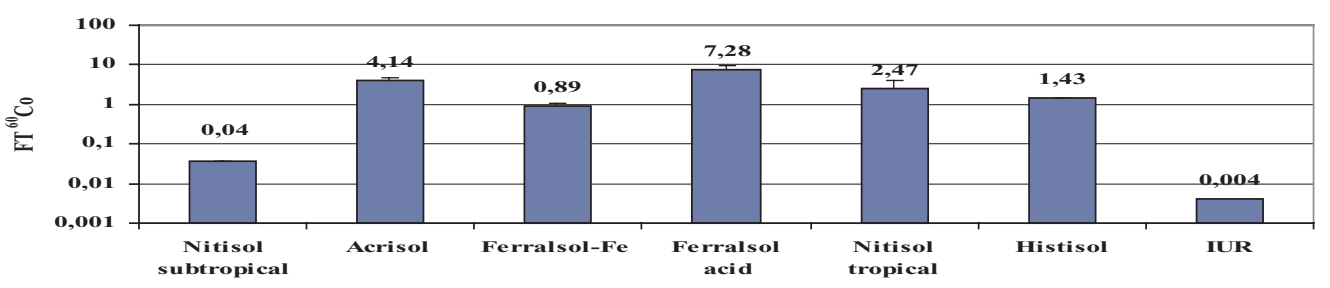

Figure 3. ${ }^{60}$ Co Soil to Plant Transfer Factor for radish.

root uptake in the Nitisol (subtropical) in the $4^{\text {th }}$ years after contamination, what was also corroborated by the low TF observed in this soil for all crops (Figures 1 and 2).

Wasserman et al. [9] studying the geochemical partitioning of ${ }^{137} \mathrm{Cs}$ in tropical and subtropical soils observed the important affinity of this radionuclide for $\mathrm{Fe}$ and for $\mathrm{Al}$ oxy-hydroxides (alkaline phase) constituting an important sink. In the case of the Nitisol, the alkaline phase can retain $67 \%$ of added ${ }^{137}$ Cs.

Furthermore, lower TF was observed for ${ }^{60} \mathrm{Co}$ in Nitisol (subtropical), and higher TF for soils lately contaminated: Ferralsol acid, Histisol and Nitisol tropical. As illustrated in Figure 3, ${ }^{60} \mathrm{Co} \mathrm{TF}$ was one order of magnitude or more, higher than the TF recommended by IUR. According to Wasserman et al. [8], soils receiving organic amendment presented an important reduction on ${ }^{60}$ Co transfer factors compared with the same soils without amendment. The results of geochemical partition showed that more than $60 \%$ of ${ }^{60} \mathrm{Co}$ was associated with Mn oxides in Nitisol and this phase was also important for other Brazilian soils $[8,9]$.

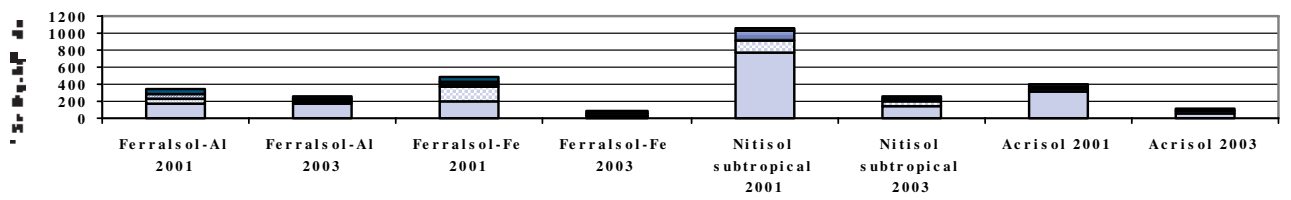

$\square$ acidic $\square$ easily reducible $\square$ oxidizable $\square$ alkaline $\square$ resistant

Figure 4. ${ }^{90} \mathrm{Sr}$ geochemical partitioning.

Results of the geochemical partition showed that more than $49 \%$ of the total ${ }^{90} \mathrm{Sr}$ in these soils are readily available for root uptake even 3 years after contamination (Figure 4), nevertheless the plant uptake seems controlled by the competition mechanisms between $\mathrm{Sr}$ and $\mathrm{Ca}$ due to the chemical similarity of both elements: soil with high content of exchangeable Ca absorb less ${ }^{90} \mathrm{Sr}$, even when this is available in the soil solution (Figure 5). Again, lower ${ }^{90} \mathrm{Sr} \mathrm{TF}$ occurred mainly for Nitisol while higher TF value occurred mainly associated with acid and unfertile soils: Acrisol and Ferralsol-Fe. 


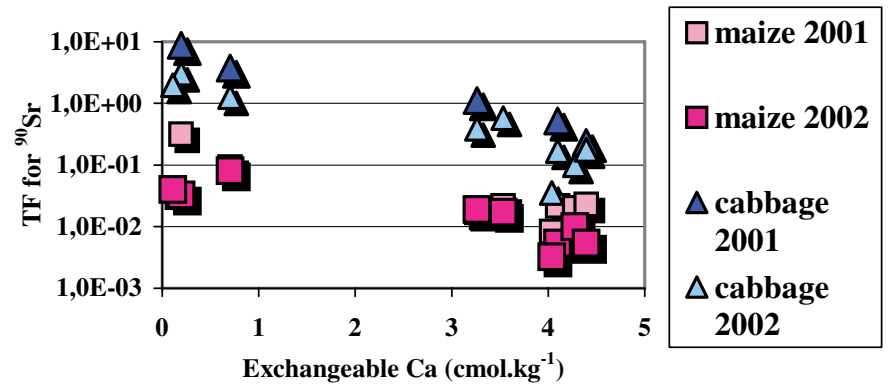

Figure 5. Soil to Plant Transfer Factor for ${ }^{90} \mathrm{Sr}$ related with exchangeable Ca.

\section{CONCLUSIONS}

These results demonstrate that well weathered soils, depleted of high activity clay minerals, such as vermiculite, were the most vulnerable soil for radioactive contamination, but for these areas, good agricultural practices guaranty better radiological protection, since it improves crop production and minimizes transfer process on soil system.

The environmental studies also stressed the relevance of the use of site specific data for environmental impact assessments and to the decision making process after an accidental contamination, that need to be based on the knowledge of environmental processes governing the long term behavior of radionuclides at a specific type of environment. This is particularly important to tropical areas because of the different soil classes used for agricultural purposes, as compared to temperate climate conditions, for which most literature data has been historically developed.

\section{Acknowledgments}

This research was done under the contract BRA10456/RO, supported by IAEA/IUR/FAO and later by the National Research Council (CNPq-Brazil) contract 478410/2004-2. The experiments were developed with the support of IRD students, Antônio Portilho, Flavia Bartoly, Aline Viana and Michele Silva. The radionuclides were determined at IRD Environmental Analytical Service - SEANA/IRD and pedological analyses were determined by EMBRAPA. The author thanks Elaine Rochedo for reviewing this paper.

\section{References}

[1] Wasserman M.A. and Belém L.M.J. "Valores de transferência do ${ }^{137}$ Cs de Latossolos para plantas comestíveis". In: Anais do VI Congresso Geral de Energia Nuclear. Rio de Janeiro, 1996.

[2] Wasserman M.A.M. "Behaviour of ${ }^{137} \mathrm{Cs}$ in Oxisols and Goiânia soil. In: Goiânia, Ten Years Later". Proceedings of a Conference, Goiânia, 26-31 October 1997, CNEN \& IAEA. 1998.

[3] Rochedo E.R.R. and Wasserman M.A. "Avaliação de impacto ambiental: uso de dados genéricos versus uso de valores específicos para o local”. Proceedings of V ENAN. Rio de Janeiro. 16-20 October 2000 (CD-ROM).

[4] Wasserman M.A., Perez D.V., Bartoly F. and Poquet I. "Assessment of the Mobility and Bioavailability of ${ }^{60} \mathrm{Co}$ and ${ }^{137} \mathrm{Cs}$ in Contaminated Soils". V Regional IRPA Congress. Brazil. 2001 (CD-ROM).

[5] Wasserman M.A., Perez D.V. and Bourg A. "Behaviour of ${ }^{137}$ Cs in Some Brazilian Oxisols". Communications in Soil Science and Plant Analysis. New York, 33, (2002) pp. 1335-1349.

[6] Bartoly F., Wasserman M.A.V., Rochedo E.R.R., Viana A.G., Pérez D., Souza R.C., Oliveira G.R., Conti C.C. and Reis W.G.S. Revista Brasileira de Pesquisa e Desenvolvimento, v. 7, (2005) pp. 176-181. 
[7] Wasserman M.A., Perez D.V., Viana A.G., Bartoly F., Silva M.M., Ferreira A.C.M., Wasserman J.C.F.A. and Bourg, A. In: 13 Internat. Conf. on Heavy metals in the Environment, Rio de Janeiro. 2005.

[8] Wasserman M.A., Bartoly F., Portilho A.P., Rochedo E.R., Viana A.G., Perez D.V. and Conti C.C. J. Environ. Radioact. 99, (2008) pp. 554-562.

[9] Wasserman M.A., Bartoly F., Viana A.G., Silva M.M., Rochedo E.R.R., Perez D.V. and Conti C.C., J. Environ. Radioact. 99, (2008) pp. 546-553.

[10] Embrapa, Manual de Métodos de Análise de Solo, Embrapa-CNPS, Brasil, 1997.

[11] International Union of Radioecologists, VI Report of the Working Group Soil-to Plant Transfer Factors. IUR, Bilthoven, Netherlands 1989.

[12] Riise G., Bjornstad H.E., Lien H.N., Oughton D.H. and Salbu B. J. Radioanal. Nucl. Chem., 142, (1990) pp. 531-538. 